\title{
Quality Assessment of Five (5) Brands of Sachet Water Marketed in Bo City
}

\author{
Solomon K. Bona, Alhaji Brima Gogra*, Bashiru M. Koroma* \\ Chemistry Department, School of Environmental Sciences, Njala University, Freetown, Sierra Leone \\ Email: ^agogra@njala.edu.sl, ‘bashiru.koroma@yahoo.com
}

How to cite this paper: Bona, S.K., Gogra, A.B. and Koroma, B.M. (2018) Quality Assessment of Five (5) Brands of Sachet Water Marketed in Bo City. Natural Resources, 9, 110-128.

https://doi.org/10.4236/nr.2018.94008

Received: December 22, 2017

Accepted: April 15, 2018

Published: April 18, 2018

Copyright ( $) 2018$ by authors and Scientific Research Publishing Inc. This work is licensed under the Creative Commons Attribution International License (CC BY 4.0).

http://creativecommons.org/licenses/by/4.0/

(c) (i) Open Access

\begin{abstract}
This study covers some physical, chemical, and bacteriological parameters needed to be tested for drinking water quality. The purpose of the research is to assess and compare the quality of five different brands of sachet water marketed in Bo city and to give relevant recommendation(s) were possible. The results obtained were compared to the standard set for each parameter by the World Health Organization (WHO) and the maximum contaminant level set by the United State Environment Protection Agency (USEPA). Five brands of sachets water were selected in Bo city and their physical and chemical parameters were evaluated in the Njala University Quality Control Laboratory (NUQCL), and their bacteriological evaluation was done in the Sierra Rutile laboratory. The physical parameters tested for were in accordance with the standards set by the WHO with the exception of the temperatures for each brand which were above the WHO standard. The $\mathrm{pH}$ of all the sachets water was in the acidic range, below the standard range and the maximum contaminant level set by the WHO and USEPA respectively. This affected the alkalinity of all the sachets water to be zero (0). None of the sachets water completely met the WHO standard and the USEPA maximum contaminant level for all the parameters tested for in this research. In this regard, none of the sachets water is completely recommended for drinking.
\end{abstract}

\section{Keywords}

Bo City, Water Quality, Sachet Water, Maximum Contaminant Level, Bacteriological, Physical and Chemical Parameters

\section{Introduction}

It is necessary to know or to determine the quality of water especially drinking water, as the common saying goes "water is life". In the human body, there is 
approximately about $70 \%$ of water, and a $1 \%$ loss of it through bodily fluids can make one thirsty, a $10 \%$ loss of it is a risk of death. This means that human beings need enough water to survive. The kind of water needed must be safe or pure water in order for it proper functioning in the human body.

In 2009, Africa's population exceeded 1 billion and continues to increase at a rate of $2.4 \%$ annually. Of this population, 341 million lack access to clean drinking water, and a further 589 million have no access to adequate sanitation. In both cases, increases in coverage are not keeping pace with population growth, which means it will be unlikely that the 2015 Millennium Development Goals will be met [1].

It is estimated that around half of all patients occupying African hospital beds suffer from water-borne illnesses due to lack of access to clean water and sanitation. This is reducing the overall health and productivity of the adult workforce. Water-borne diseases like typhoid, cholera and dysentery are among the major causes of mortality and morbidity in Africa. Lack of safe water and sanitation costs sub-Saharan Africa around 5\% of its Gross Domestic Product (GDP) each year. Households in rural Africa spend an average of $26 \%$ of their time fetching water; generally women are burdened with this task [1].

Water pollution (particularly drinking water) is a serious problem in Sierra Leone. Almost half of the population of Sierra Leone has no access to safe drinking water and only $13 \%$ of the population has access to improved nonshared sanitation facilities. Some $74 \%$ of urban dwellers have access to safe drinking water while only $46 \%$ of rural people use safe water. In the Northern Region, only $30 \%$ of residents have access to safe drinking water. According to the Sierra Leone Water Company, on average only 35\% of rural residents have access to safe drinking water. According to the Ministry of Energy and Water Resources, in order to meet Millennium Development Goal targets, annual increments of about $3 \%$ and $3.9 \%$ of the population having access to improved water sources and sanitation, respectively, are needed. The majority of Sierra Leonean households do not have access to improved sanitation and the situation continues to deteriorate. Between 2005 and 2008, the proportion of the population with improved sanitation decreased from 30\% (24\% urban, 6\% rural) to $13 \%[2]$.

In the year 2001-2003, Sierra Leoneans started to sell a cup or few cups of water in which so many consumers drink from the same cup. Some issues concerning health were brought up that such usage of drinking from the same cup transmit diseases such as tuberculosis (TB), typhoid and cholera from one person to another. Not too long after that people started to packet water in polythene bags, tied with hands. But this also had a problem of contamination during the processes of production since bare hands were used in each stage of production. The processes were not complex, the sellers fetch the water either from bore holes, streams or hand pump, filter it by using white linen cloth, and the polythene bags were opened by mouth-blowing of air, which was a potential 
source of introducing bacteria, and the polythene is sealed by tying a knot at one end, and then it is cooled in the refrigerator for sale. This is all done without any form of chlorination nor sterilization.

In the year 2005-2006, the production of sachet water by the Grafton Company was introduced in Sierra Leone as an improvement on the hand-filled and hand tied plastic water. Since then the consumption of sachet water increased because people see it as the best source of good drinking water, and the change in lifestyle towards the consumption of sachet water. This has led to the increase of many producers of sachet water both large-scale and small-scale entrepreneurs. Some of these producers do not have the knowledge as to how to take cognizance to the standards of hygienic production practices. So because of the profit people see in the production of sachet water, they just produce it in large quantities without considering the qualities.

Water and sanitation is a major issue all over the world but most especially in developing countries such as Sierra Leone. One of the fights for a safe drinking water is seen as the production of sachet water. There are many large-scale and small-scale entrepreneurs who have come into the business of producing sachet water but yet still, Sierra Leoneans are still struggling with water borne diseases especially from drinking water, even the very sachet water.

In an investigation carried out by National Agency for Food and Drug Administration and Control (NAFDAC) which was established and saddled with the responsibility, among others, of regulation of packaged water and ensuring quality in the production and packaging of water, between 2004 and 2005, it was revealed that some producers of these sachet water indulge in sharp practices such as packaging of untreated water, production under unhygienic conditions, illegal production of unregistered water in unapproved premises, use of non-food grade sachets and release of packaged water for distribution and sale without date marking.

Since there is no strict observation by the ministry of energy and water resources that is charged with the responsibility of doing routine water quality testing, it seems as if these producers are only busy producing very large quantity of sachet water and selling it to the masses without considering their quality.

A case study on the outbreak of cholera was done by the WHO and they found out that as of 19 September, 2012, there were more than 19,000 cases and 274 deaths. According to the WHO, water and sanitation are the key; water and sanitation remain a long-term challenge, particularly in urban slums where people are at high risk of cholera infection. "Until there is a significant improvement in the water and sanitation infrastructure, Sierra Leone will continue to be vulnerable to cholera, especially in the rainy season," says Perea [3]. Up till now diseases like cholera, dysentery, typhoid etc. are still prevalent in Sierra Leone even though people are drinking these so called "sachet water".

There are many complains concerning the quality of sachet water produced all most all over the country and it seems as if nobody cares not even the ministry 
that is expected to carry it as its responsibility, and complains about their smell, colour, taste, sediments, and even the after effect of drinking it.

Bo City is the second capital city of the country, and almost about $60 \%$ of its population drink sachet water as their only hope of quality drinking water, but yet still they are having problems with them. Some people even prefer drinking from their bore holes and hand pumps instead of drinking sachet water.

This among many other concerns about sachet water makes it necessary for a scientific investigation in to the quality of packaged water produced and/or sold in Bo City.

\section{Materials and Methods}

\subsection{Description of Study Area}

Bo City was chosen as a study area because it is the second largest city of Sierra Leone. Also it is one of the most populated city of the country consisting of a population of 574,201 that is $8.1 \%$ of the total population of Sierra Leone [4]. There are numerous sachets and quite a number of bottled drinking water sold and/or produced in Bo-City, with consumption of sachet water higher than bottled drinking water owing to cost difference.

\subsection{Sampling of Five (5) Different Brands of Sachet Water}

Five (5) different brands of sachet water were analyzed in this study. These different brands from different manufacturers are the most consumed sachet water in the city. A bundle of each brand of the sachet water was purchased from different shops since they do not have batch numbers, and six sachets from each brand bundle were placed in a cool-man and then were taken directly to the Njala University Quality Control Laboratory (NUQCL). The edge of each sachet to be tested was cut with a sterilized scissors and carefully placed in a sterilized beaker. The physical, chemical parameters were determined by taking water directly from the original sachet water that was cut open.

Some of the samples of each brand were placed in a cool-man with ice and were taken to the Rutile Laboratory to do the bacteriological test.

\subsection{Physical Analysis}

\subsubsection{Determination of Temperature}

The instrument used for the temperature measurement was the mercury in glass thermometer (GH ZEAL LTD-LONDON-ENGLAND $76 \mathrm{~mm} 1 \mathrm{~mm}$ ).

Three replicate readings were taken for each sample. One was taken in the afternoon at the point of purchase by cutting the plastic with a sterilized scissors and then the thermometer was dipped into each sample one after the other after it has been wiped with a tissue paper. The other temperature readings were taken in the morning and then in the evening by the same method.

\subsubsection{Determination of Conductivity}

The conductivity was measured using the Digital Conductivity Meter....611. The 
meter was first calibrated by setting the temperature knob at $25^{\circ} \mathrm{C}$, and the function knob was turned to check and adjust the display value to 1.00 by turning the screw at the back of the instrument. The range knob was set at $200 \mu \mathrm{S} / \mathrm{cm}$. The function knob was turned at the cell constant. The probe was then dipped into a $0.1 \mathrm{M}$ potassium chloride $(\mathrm{KCl})$ solution and the reading was adjusted to 1.408 with the cell constant knob. The function knob was then turned on and the value displayed was recorded.

$20 \mathrm{ml}$ of each sample was poured into a beaker. The probe was dipped into each sample one after the other. After it is removed from one sample, it is dipped into a distilled water and then wiped thoroughly with tissue paper before it is dipped into another sample. The steady value displayed on the screen is taken as the conductivity measurement for each sample. Three replicate measurements were recorded for each sample, one in the morning, the other in the afternoon, and the next in the evening.

\subsubsection{Determination of Turbidity}

Turbidity was determined ex-situ in the laboratory by using the HACH $2100 \mathrm{Q}$ turbidimeter measured in nephlometer turbidity unit (NTU).

The instrument was calibrated first with standards 10 (verification standard), 20,100 , and 800 respectively. After calibration, a little of each sample is poured into their labelled clean oiled turbidity vial after the sample had been inverted several times. The turbidity vial were filled to the white line, gently inverted several times and then placed in to the turbidimeter. A measurement was obtained by waiting 20 seconds, watching the digital readout on the turbidimeter for 30 seconds and determining the average reading. Three replicate measurements were recorded for each sample, one in the morning, the other in the afternoon, and the next in the evening.

\subsubsection{Determination of Total Dissolved Solids (TDS)}

Five (5) conical flasks were washed properly and then rinsed with distilled water. The conical flasks were allowed to dry properly by putting them in an ovum for about 10 minutes, and then they were weighed.

$50 \mathrm{ml}$ of each sample was poured through a filter paper into their labelled conical flask. They were then placed into an ovum for complete evaporation. After a total evaporation, the conical flasks were weighed again. The TDS was determined by using the Equation (1) below:

TDS $=$ Weight of flask after evaporation - Weight of flask before evaporation (1)

The units obtained were in $\mathrm{g} / \mathrm{ml}$ which was then converted into $\mathrm{mg} / \mathrm{L}$ by using the first principle i.e. the conversion method.

\subsection{Chemical Analysis}

\subsubsection{Determination of $\mathrm{pH}$}

The instrument used to measure the $\mathrm{pH}$ was the HANNA INSTRUMENTS $\mathrm{pH}$ meter. 
$20 \mathrm{ml}$ of each sample was measured into a cylinder after it is rinsed with the sample to be measured and then poured into it labelled beaker. The $\mathrm{pH}$ meter was then inserted into each beaker one after the other after it is rinsed in a distilled and then wiped with a tissue paper. Three replicate $\mathrm{pH}$ readings were taken for each sample, one in the morning, the other in the afternoon, and the next in the evening.

\subsubsection{Determination of Chemical Oxygen Demand (COD)}

Preparation of Reagents used

- $\mathrm{K}_{2} \mathrm{Cr}_{2} \mathrm{O}_{7}(0.1 \mathrm{M}) 14.709 \mathrm{~g} \rightarrow 500 \mathrm{ml}$ distilled water

- Sodium thiosulphate $24.818 \mathrm{~g} \rightarrow 1 \mathrm{~L}$ distilled water

- Potassium Iodide (KI) $5 \mathrm{~g} \rightarrow 500 \mathrm{ml}$ distilled water

- Starch solution $10 \mathrm{~g} \rightarrow 100 \mathrm{ml}$ distilled water Procedure

- Pipette $10 \mathrm{ml}$ of water sample into $125 \mathrm{ml}$ conical flask

- Add $5 \mathrm{ml} \mathrm{K}_{2} \mathrm{Cr}_{2} \mathrm{O}_{7}$

- Heat in a water bath at $100^{\circ} \mathrm{C}$ for 1 hour

- Allow to cool for 10 minutes

- Add $5 \mathrm{ml}$ of Potassium iodide (KI)

- Add $10 \mathrm{ml}$ of sulphuric acid $\mathrm{H}_{2} \mathrm{SO}_{4}$

- Add $1 \mathrm{ml}$ of starch solution to give a blue colour

- Titrate with sodium thiosulphate until the blue colour disappears completely. Equation (2) used to calculate COD was taken from Guide to Laboratory Establishment for Plant Nutrient Analysis is shown below:

$$
\text { COD mg/L }=(A-B) * 0.1 * 80
$$

where $A$ is the volume of sodium thiosulphate used for sample

$B$ is the volume of sodium thiosulphate used for blank sample

0.1 is the concentration of $\mathrm{H}_{2} \mathrm{SO}_{4}$

80 is the standard percentage of the acid

\subsubsection{Determination of Nitrate-Nitrogen}

This method depends on the reduction of nitrate to ammonia by adding Devarda's alloy and alkali. The nitrites $\left(\mathrm{NO}_{2}^{-}\right)$(if present) in the sample are also reduced and determined along with $\mathrm{NO}_{3}^{-}-\mathrm{N}$.

The apparatus required consists of:

- A Kjeldahl distillation assembly;

- An electric muffle furnace;

- A desiccator

Reagent preparation

- Heat $\mathrm{MgO}$ at $65^{\circ} \mathrm{C}$ for 2 hours in an electric ovum to remove any trace of $\mathrm{MgCO}_{3}$ that may be present. Remove and allow to cool in a beaker

- Mixed indicator: $0.666 \mathrm{~g}$ of methyl red and $0.999 \mathrm{~g}$ of bromocresol green, and dissolve in $100 \mathrm{ml}$ of alcohol 
- Boric acid: weigh $20 \mathrm{~g}$ of boric acid into $1000 \mathrm{ml}$ volumetric flask. Add about $500 \mathrm{ml}$ of distilled water

- Allow to cool then add $20 \mathrm{ml}$ of mixed indicator. Then make the volume to the $1 \mathrm{~L}$ mark

- Standard $\mathrm{H}_{2} \mathrm{SO}_{4}$ : $5.6 \mathrm{ml} \mathrm{H}_{2} \mathrm{SO}_{4}$ to about $1 \mathrm{~L}$ of distilled water. Take $20 \mathrm{ml}$ from this solution and dilute to $100 \mathrm{ml}$ distilled water Procedure

- Measure $50 \mathrm{ml}$ of water sample into the distillation flask

- Add $0.5 \mathrm{~g}$ of $\mathrm{MgO}$ and $0.2 \mathrm{~g}$ of Devarda's alloy powder

- Put the heaters on and collect the $\mathrm{NH}_{4}\left(\mathrm{NO}_{3}\right.$ converted into $\mathrm{NH}_{4}$ by reducing agent-Devarda's alloy) in boric acid $(20 \mathrm{ml})$ having mixed indicator into a conical flask, which is connected with distillation apparatus.

- Continue distillation to collect about 35 - $40 \mathrm{ml}$.

- Remove the distillate first and then switch off the heating system.

- Titrate the distillate against $0.02 \mathrm{M} \mathrm{H}_{2} \mathrm{SO}_{4}$ until the pink colour appears.

- Carry out a blank simultaneously.

The relevant calculation is [using Equation (3)]:

$$
\mathrm{NO}_{3}^{-}-\mathrm{N}(\mathrm{mg} / \mathrm{L})=\frac{(X-Y) \times 0.56}{50(\mathrm{ml} \text { of sample })} \times 1000
$$

where:

- $X=$ Volume $(\mathrm{ml})$ of $0.02 \mathrm{M} \mathrm{H}_{2} \mathrm{SO}_{4}$ consumed in sample titration;

- $Y=$ Volume (ml) of $0.02 \mathrm{M} \mathrm{H}_{2} \mathrm{SO}_{4}$ consumed in blank titration

- 0.56 = factor. 1 litre $1 \mathrm{M} \mathrm{H}_{2} \mathrm{SO}_{4}=28 \mathrm{~g} \mathrm{~N}$; therefore:

$$
1 \mathrm{ml} 0.02 \mathrm{M} \mathrm{H}_{2} \mathrm{SO}_{4}=\frac{28 \times 0.02 \times 1000}{1000} \mathrm{mg} \mathrm{N}=0.56 \mathrm{mg} \text {. }
$$

\subsubsection{Determination of Available Chlorine}

The available chlorine will release iodine from potassium iodide solution. The released iodine is titrated with standard solution of sodium thiosulphate.

Reagent preparation

- Acetic acid $\rightarrow$ diluted $1: 3(83.3 \mathrm{ml} \rightarrow 250 \mathrm{ml}$ flask distilled water $)$

- Potassium iodide $\rightarrow 10 \%(25 \mathrm{~g} \rightarrow 250 \mathrm{ml}$ flask distilled water $)$

- Sodium thiosulphate $\rightarrow 0.1 \mathrm{~mol} / \mathrm{L}(24.818 \mathrm{~g} \rightarrow 1 \mathrm{~L})$

- Starch solution $\rightarrow(10 \mathrm{~g} \rightarrow 100 \mathrm{ml})$ Apparatus

- Titration flask -------- $250 \mathrm{ml}$

- Pipettes -------- $10 \mathrm{ml}, 20 \mathrm{ml}, 25 \mathrm{ml}$

- Burette capacity $50 \mathrm{ml}$, graduated $0.1 \mathrm{ml}$ intervals. Procedure

- Pipette $20 \mathrm{ml}$ of the sample into a $250 \mathrm{ml}$ filtration flask

- Add $20 \mathrm{ml}$ of potassium iodide

- Add $10 \mathrm{ml}$ of acetic acid

- Titrate with sodium thiosulphate to a bright yellow colour 
- Add $2 \mathrm{ml}$ of starch and titrate until the solution becomes colourless.

The available $\mathrm{Cl}(\mathrm{X})$ in $\mathrm{g} / \mathrm{L}$ can be calculate using Equation (4):

$$
X=f \times b \times c_{1} \times M=f \times b \times 0.1 \times 35.453 \quad=
$$

$X=f \times b \times 3.545$

where $f$ is factor of $\mathrm{Na}_{2} \mathrm{~S}_{2} \mathrm{O}_{3}$ volumetric solution

$b=$ consumption of $\mathrm{Na}_{2} \mathrm{~S}_{2} \mathrm{O}_{3}$ volumetric solution in $\mathrm{ml}$

$C_{1}=$ concentration of $\mathrm{Na}_{2} \mathrm{~S}_{2} \mathrm{O}_{3}$ volumetric solution $\left(C_{1}=0.1 \mathrm{M}\right)$

$M=$ chlorine molecular weight $(M=35.453 \mathrm{~g} / \mathrm{mol})$

Calculating the factor of $\mathrm{Na}_{2} \mathrm{~S}_{2} \mathrm{O}_{3}$

$1 \mathrm{~L}$ of $1 \mathrm{M} \mathrm{Na}_{2} \mathrm{~S}_{2} \mathrm{O}_{3}=35.45 \mathrm{~g}$ of $\mathrm{Cl}$; therefore:

$1 \mathrm{~L}$ of $0.1 \mathrm{M} \mathrm{Na}_{2} \mathrm{~S}_{2} \mathrm{O}_{3}=\frac{35.45 \times 0.1 \times 1000}{1000}=3.545 \mathrm{mg}$ of $\mathrm{Cl}=0.003545 \mathrm{~g}$ of Cl

Therefore $X=0.003545 \times 0.1 \times 3.5453=0.0013 \mathrm{~g} / \mathrm{L}$

The answer gotten in $\mathrm{g} / \mathrm{L}$ for the active chlorine can then be converted to $\mathrm{mg} / \mathrm{L}$ using the first principle.

\subsubsection{Determination of Alkalinity}

The estimation is based on simple acidimetric titration using different indicators that work in the alkaline (higher than 8.2 ) or acidic $\mathrm{pH}$ range (lower than 6.0 ) [5].

The apparatus required consists of:

- A porcelain dish;

- A burette

The reagents required are:

- Phenolphthalein indicator: 0.25 percent solution in 60 percent ethyl alcohol.

- Methyl orange indicator: 0.5 percent solution in 95 percent alcohol.

- Standard sulphuric acid (0.01 M) Procedure

- Put $5 \mathrm{ml}$ of the water sample (containing not more than one milli-equivalent of carbonate plus bicarbonate) in porcelain dish.

- Dilute with distilled water to about $25 \mathrm{ml}$.

- A pink colour produced with 2 - 3 drops of phenolphthalein indicates the presence of carbonate, and it is titrated with $0.01 \mathrm{M}$ sulphuric acid until the colour just disappears (phenolphthalein end point) because of alkaline carbonate having been converted to bicarbonate. This is called the half-neutralization stage. This burette reading (volume used) is designated Y.

- To the colourless solution from this titration (or to the original sample of the water if there was no colour with the phenolphthalein), add $1-2$ drops of methyl orange indicator, and continue titration with brisk stirring to the methyl orange end point (yellow); the final reading (volume used) is designated $\mathrm{Z}$.

The relevant calculation is [using Equation (5)]: 


$$
\begin{aligned}
& \text { Carbonates }(\mathrm{me} / \mathrm{L}) \\
& =2\left(\text { volume of } \mathrm{H}_{2} \mathrm{SO}_{4}\right) \times \text { molarity of } \mathrm{H}_{2} \mathrm{SO}_{4} \times \frac{1000}{\mathrm{ml} \text { of aliquot }} \\
& =2 Y \times 0.01 \times \frac{1000}{5} \\
& \text { Carbonates }(\mathrm{g} / \mathrm{L}) \\
& =\frac{2\left(\text { Vol. of } \mathrm{H}_{2} \mathrm{SO}_{4}\right) \times \text { Molarity } \times 1000 \times \text { Eq.wt.of } \mathrm{CO}_{3}(30)}{\mathrm{ml} \text { of sample } \times 1000} \\
& =\frac{2 Y \times 0.01 \times 30}{5}-0.12 Y
\end{aligned}
$$

The volume of acid used for half-neutralization of carbonate is $Y$. Hence, for full neutralization it has been assumed as $2 Y$.

\subsection{Bacteriological Analysis}

\subsubsection{Determination of Faecal and Total Coliforms}

\section{Procedure}

The Membrane filter technique, according to Standard Operating Procedure manual/reference material was used to investigate the bacteriological status of samples collected.

Growth absorbent pads were dispensed with pad dispenser into twelve (12) sterile petri-dishes and labeled "FC" (from 1 - 5) for fecal Coliforms testing and TC (from 1 - 5) for total coliforms testing. Two sterile petri-dishes were set as blank for both faecal and total Coliforms.

The pad were saturated or soaked with membrane Lauryl Sulphate Broth (MLSB). Forceps were sterilized using a flame and allowed to cool, after which, methanol was smeared on them.

Using these forceps, sterile membrane filters were placed onto the bronze membrane support and covered with the filtration funnel. $10 \mathrm{ml}$ of water sample was poured into the filter funnel and a hand vacuum pump connected to the filtration unit base was pumped to suck the water sample through the membrane. Sterile forceps were used to remove the membrane filter from the bronze membrane support after the water has been filtered. The membrane filter was then placed on the pad in the petri-dish which had been saturated or soaked with the MLSB media. This was repeated for the various water samples. The lids for the petri-dish were replaced immediately. The membrane filter was placed on top of the soaked pads and the petri-dishes were placed in a petri-dish rack. When the last sample had been processed, a resuscitation period of about 30 minutes was observed before incubating. For the incubation of fecal coliforms, a temperature of $44^{\circ} \mathrm{C}$ was selected on the incubator and $37^{\circ} \mathrm{C}$ for that of total coliforms. The racks were placed into the incubator for 24 hours for observation and counting of colonies. Yellow colonies indicated that fecal coliforms were present and pink colonies indicated total coliforms. Counting was done with the aid of a hand lens and the estimated bacteria present per $10 \mathrm{ml}$ of water sample calculated using Equation (6): 
Estimated bacteria present per $10 \mathrm{ml}$ of water sample

$$
=\frac{\text { NUMBER OF COLONY FORMING UNITS }}{\text { VOLOUME OF SAMPLE WATER FILTERED }} \times 100
$$

\subsubsection{Determination of Non-Faecal Coliforms}

The non-faecal coliforms growth was calculated by using the Equation (7):

Non-faecal Coliforms $=$ Total Coliforms growth - Faecal Coliforms growth (7)

\section{Results and Discussions}

\subsection{Physical Parameters}

\subsubsection{Temperature}

The mean temperature of all the brands of sachet water is above the standard set by the WHO which is $25^{\circ} \mathrm{C}$ (Table 1 ). This could be because of the environment in which they are stored. The afternoon temperatures are so high which might be because of the high temperature of the sun, these were taken at the point of purchase. Temperature affects a number of other water quality parameters such as COD i.e. when temperature increases, COD increases too, and even the microbiological aspects of water.

These temperatures obtained fall within the optimal growth temperature $\left(20^{\circ} \mathrm{C}-45^{\circ} \mathrm{C}\right)$ for mesophilic bacteria including human pathogens [7]. The microbiological characteristics of drinking water are related to temperature through its effects on water-treatment processes and its effects on both growth and survival of microorganisms [8].

Consequently, growth of nuisance microorganism is enhanced by warm water conditions and could lead to the development of unpleasant tastes and odours [9]. However, a report [10] by State Water Quality Control Board in Canada indicated that the survival time in water of the cysts and ova of parasitic worms such as Schistosoma ova is shortened by higher temperatures between $29^{\circ} \mathrm{C}$ to $32^{\circ} \mathrm{C}$.

A study on the "storage effects on the quality of sachets water produced within Port Harcourt Metropolis, Nigeria" published in the Jordan Journal of Biological Sciences, it was discovered that "under prolonged storage of packaged water at favorable environmental conditions (temperature values ranging from 27.1 to $28.8^{\circ} \mathrm{C}$, averaging $27.9^{\circ} \mathrm{C}$ ), total aerobic heterotrophic bacteria can grow to levels

Table 1. Temperature (Source: Author's research data, 2016).

\begin{tabular}{ccccc}
\hline \multirow{2}{*}{ Sample Brands } & \multicolumn{4}{c}{ Temperature $\left({ }^{\circ} \mathrm{C}\right)$} \\
\cline { 2 - 5 } & Morning $(9-10 \mathrm{am})$ & Afternoon $(1-2 \mathrm{pm})$ & Evening $(5-6 \mathrm{pm})$ & Mean \\
\hline TEX & 26.5 & 30.1 & 25 & $\mathbf{2 7 . 2 0}$ \\
Blue Diamond & 27 & 31.6 & 26.5 & $\mathbf{2 8 . 3 7}$ \\
JAH & 25.5 & 31.5 & 26.5 & $\mathbf{2 7 . 8 3}$ \\
KUMA & 26 & 31.5 & 26 & $\mathbf{2 7 . 8 3}$ \\
JAGISA & 26.5 & 29.6 & 25 & $\mathbf{2 7 . 0 3}$ \\
\hline
\end{tabular}

(WHO GUIDELINE, $1996=25^{\circ} \mathrm{C}$ ) [6]. 
that may be harmful to humans, and consumption of water containing large numbers of total aerobic heterotrophic bacteria can lead to diseases such as gastroenteritis and mucous membrane infections, particularly in persons whose immune systems are compromised by AIDS, organ transplantation or chemotherapy.

\subsubsection{Electrical Conductivities}

The conductivity values give us a rapid and inexpensive way of determining the ionic strength of the water samples (Table 2). This is an easy measurement to make and relate closely to the total dissolved solids content of the sachet waters.

The electrical conductivity measured for all the sachets water are below the standard set by the WHO which is $250 \mu \mathrm{S} / \mathrm{cm}$ with the highest being Blue Diamond and JAH. If conductivity increases, it indicates that there is a source of dissolved ions in the vicinity. This clearly showed that all the sachet waters contain fewer amounts of dissolved ions or salts, though some are higher than others.

The conductivity depends on the value of the $\mathrm{pH}$, on the temperature of measurement and the amount of $\mathrm{CO}_{2}$ which has been dissolved in the water to form ions. The conductivity is also affected by the concentration of ions already present in the water such as chloride, sodium and ammonium. Chemical composition of water determines its conductivity. Hence this becomes the most widely used measure of the purity of water.

\subsubsection{Turbidity}

The mean turbidity values for all the sachet waters are far below the standard set by the WHO which is $5 \mathrm{NTU}$ and also within the range of $0.5-1.0 \mathrm{NTU}$ (Nephlometer turbidity unit) set by the USEPA (Table 3 ). This could be attributed to the fact that, all the sachet waters passed through series of filters, or efficient filter medium during production to remove suspended clay particles, trace elements and suspended solids. This also shows that the colour of all the sachet waters might be below the detection limit i.e. contains less dissolved humic acids.

Higher turbidity levels are often associated with higher levels of diseasecausing microorganisms such as viruses, parasites and some bacteria. These

Table 2. Electrical Conductivity (Source: Author's research data, 2016).

\begin{tabular}{ccccc}
\hline \multirow{2}{*}{ Sample Brands } & \multicolumn{4}{c}{ Electrical Conductivity $(\mu \mathrm{S} / \mathrm{cm})$} \\
\cline { 2 - 5 } & Morning & Afternoon & Evening & Mean \\
\hline TEX & 73.5 & 86.7 & 79.6 & 79.93 \\
Blue Diamond & 101.0 & 116.3 & 114.5 & 110.6 \\
JAH & 115.9 & 121.5 & 119.3 & 118.77 \\
KUMA & 102.3 & 105.5 & 100.0 & 102.6 \\
JAGISA & 90.5 & 96.5 & 89.4 & $\mathbf{9 2 . 1 3}$ \\
\hline
\end{tabular}

(WHO GUIDELINE, 1998: $250 \mu \mathrm{S} / \mathrm{cm}$ ) [11]. 
organisms can cause symptoms such as nausea, cramps, diarrhea, and associated headaches.

Science has proven that as turbidity increases, the risk for gastrointestinal illness also increases-particularly for at-risk populations such as newborns, the elderly, and people with weakened immune systems e.g. those with HIV/Aids, undergoing chemotherapy, or taking anti-rejection drugs following a transplant [14].

\subsubsection{Total Dissolved Solids}

The TDS values recorded for all the sachet waters fall below the standard set by the WHO $(248 \mathrm{mg} / \mathrm{L})$ and the Maximum Contaminants Level (MCL) set by the USEPA which is $500 \mathrm{mg} / \mathrm{L}$ with the highest being Blue Diamond (Table 4). The low level of TDS could be because the water treatment plants use flocculants to aggregate suspended and dissolved solids into particles large enough to settle out of the water column in settling tanks. A flocculent is a chemical that uses double-layer kinetics to attract charged particles.

This shows that the concentration of dissolved organic and inorganic chemicals for all the water samples is small to cause any harm.

\subsection{Chemical Parameters}

\subsubsection{Hydrogen Ion Concentration $(\mathrm{pH})$}

The mean $\mathrm{pH}$ values for all the sachet waters fall outside the standard set by the

Table 3. Turbidity (Source: Author's research data, 2016).

\begin{tabular}{ccccc}
\hline \multirow{2}{*}{ Sample Brands } & \multicolumn{4}{c}{ Turbidity (NTU) } \\
\cline { 2 - 5 } & Morning & Afternoon & Evening & Mean \\
\hline TEX & 0.59 & 0.50 & 0.49 & $\mathbf{0 . 5 3}$ \\
Blue Diamond & 0.44 & 0.33 & 0.39 & $\mathbf{0 . 3 9}$ \\
JAH & 0.47 & 0.37 & 0.50 & $\mathbf{0 . 4 5}$ \\
KUMA & 0.59 & 0.57 & 0.56 & $\mathbf{0 . 5 7}$ \\
JAGISA & 0.36 & 0.38 & 0.32 & $\mathbf{0 . 3 5}$ \\
\hline
\end{tabular}

(WHO GUIDELINE, $1984 \leq 5$ ) [12]. (USEPA MCL 10/1996 = 0.5 - 1.0) [13].

Table 4. Total Dissolved solids (TDS) (Source: Author's research data, 2016).

\begin{tabular}{cccccc}
\hline $\begin{array}{c}\text { Sample } \\
\text { brands }\end{array}$ & $\begin{array}{c}\text { Volume of } \\
\text { filtered sample } \\
(\mathrm{mL})\end{array}$ & $\begin{array}{c}\text { Weight }(\mathrm{g}) \text { of } \\
\text { beaker before } \\
\text { evaporation }\end{array}$ & $\begin{array}{c}\text { Weight }(\mathrm{g}) \text { of } \\
\text { beaker after } \\
\text { evaporation }\end{array}$ & $\begin{array}{c}\text { TDS in } \\
\mathrm{g} / \mathrm{L}\end{array}$ & $\begin{array}{c}\mathrm{TDS} \text { in }(\mathrm{mg} / \mathrm{L})=\mathrm{TDS} \\
\text { in } \mathrm{g} / \mathrm{L} \times 20^{*} \times 1000\end{array}$ \\
\hline TEX & 50 & 71.579 & 71.584 & 0.005 & 100 \\
Blue Diamond & 50 & 90.941 & 90.951 & 0.01 & 200 \\
JAH & 50 & 77.134 & 77.142 & 0.008 & 160 \\
KUMA & 50 & 88.653 & 88.661 & 0.008 & 160 \\
JAGISA & 50 & 70.993 & 70.998 & 0.005 & 100 \\
\hline
\end{tabular}

(Note: $20^{*}=$ dilution factor). (WHO GUIDELINE, 1984 $\leq 248$ ) [12]. (USEPA MCL 10/1996 = 500 mg/L) [13]. 
WHO and the USEPA which is $6.5-8.5 \mathrm{pH}$ unit (Table 5). Low values are most often caused by lack of carbonate minerals, such as calcium and magnesium found in limestone and dolomite rocks. Water leaking from a landfill may also lower $\mathrm{pH}$. This means all the sachet waters are acidic and corrosive especially TEX and Blue Diamond, for the lower the $\mathrm{pH}$, the more corrosive the water would be.

Corrosive water can sometimes have health implications if it causes elements like lead and copper from pipes and solders to dissolve into drinking water.

\subsubsection{Chemical Oxygen Demand (COD)}

The COD level ranges from $0.0-21.0 \mathrm{mg} / \mathrm{L}$. From the table, TEX, JAH and JAGISA have COD level below the guideline which is $10 \mathrm{mg} / \mathrm{L}$. With JAH having the least below $0.0 \mathrm{mg} / \mathrm{L}$ which might be either because of the concentration is too low for the detection limit of the method used or even lower than the volume used for the blank sample as shown in Table 6.

The COD level for KUMA and Blue Diamond are above the set guideline with Blue Diamond having the highest of $20.8 \mathrm{mg} / \mathrm{L}$. Higher COD levels mean a greater amount of oxidizable organic material in the sample, which will reduce dissolved oxygen (DO) levels. A reduction in DO can lead to anaerobic conditions, which is deleterious for drinking and even for aquatic life. The COD test is often used as an alternate to BOD due to shorter length of testing time.

Table 5. Hydrogen ion concentration (pH) (Source: Author's research data, 2016).

\begin{tabular}{ccccc}
\hline \multirow{2}{*}{ Sample Brands } & \multicolumn{4}{c}{$\mathrm{pH}(\mathrm{pH}$ unit) } \\
\cline { 2 - 5 } & Morning & Afternoon & Evening & Mean \\
\hline TEX & 4.6 & 3.8 & 4.0 & 4.1 \\
Blue Diamond & 5.0 & 4.7 & 4.4 & 4.7 \\
JAH & 5.1 & 5.0 & 5.3 & $\mathbf{5 . 1}$ \\
KUMA & 5.2 & 5.8 & 6.0 & $\mathbf{5 . 7}$ \\
JAGISA & 6.5 & 6.0 & 5.8 & $\mathbf{6 . 1}$ \\
\hline
\end{tabular}

(WHO GUIDELINE, $1984=6.5$ - 8.5) [12]. [USEPA Maximum Contaminant Level (MCL) 10/1996 = 6.5 8.5] [13].

Table 6. Chemical Oxygen Demand (COD) (Source: Author's research data, 2016).

\begin{tabular}{cccccc}
\hline Sample & $\begin{array}{c}\text { Final } \\
\text { reading }(\mathrm{mL})\end{array}$ & $\begin{array}{c}\text { Initial } \\
\text { reading }(\mathrm{mL})\end{array}$ & $\begin{array}{c}\text { Volume }(\mathrm{ml}) \text { used for } \\
\text { blank sample }(\mathrm{B})\end{array}$ & $\begin{array}{c}\text { Volume }(\mathrm{ml}) \text { used for } \\
\text { water samples }(\mathrm{A})\end{array}$ & $\begin{array}{c}\text { COD in } \\
(\mathrm{mg} / \mathrm{L})\end{array}$ \\
\hline KUMA & 11.8 & 0.0 & 10.3 & 11.8 & 12 \\
TEX & 22.5 & 11.8 & 10.3 & 10.7 & 3.2 \\
Blue Diamond & 35.4 & 22.5 & 10.3 & 12.9 & 20.8 \\
JAH & 44.1 & 35.4 & 10.3 & 8.7 & $<0.0$ \\
JAGISA & 11.3 & 0.0 & 10.3 & 11.3 & 8 \\
\hline
\end{tabular}

COD, BOD limits in drinking water $\leq 10 \mathrm{mg} / \mathrm{L}$ [15]. 


\subsubsection{Nitrate-Nitrogen}

The nitration concentration for the sachet waters falls within the range of 6.70 $20.20 \mathrm{mg} / \mathrm{L}$. From Table 7, Blue Diamond, JAGISA, and KUMA have nitrate level concentration below the WHO and USEPA standard. The nitrate concentration for TEX and JAH falls above the standard set by the WHO and USEPA which is $10 \mathrm{mg} / \mathrm{L}$, TEX having the highest far above the WHO and USEPA standard. The high values might be due to improper distillation process to remove the nitrate content or due to improper reverse osmosis process.

Nitrate nitrogen is a commonly used lawn and agricultural fertilizer. It is also a chemical formed in the decomposition of waste materials. If infants under six months of age drink water (or formula made with water) that contains more than $10 \mathrm{mg} / \mathrm{L}$ nitrate-nitrogen, they are susceptible to methaemoglobinaemia, a disease which interferes with oxygen transport in the blood. Pregnant women should also avoid drinking water high in nitrate. Recent studies suggest connections between high-nitrate water and birth defects or miscarriages. High nitrate value also suggest that other contaminants may be present [16].

\subsubsection{Residual Chlorine}

The chlorine level for all the sachet water is far below the maximum contaminant level (MCL) of $4 \mathrm{mg} / \mathrm{L}$ set by the USEPA (Table 8). All the samples contain the same amount of residual chlorine, this might be because of the right amount of chlorine dose used to disinfect the waters by the companies. The residual chlorine will not be that high. The potential health effects from ingestion of water containing more than $4 \mathrm{mg} / \mathrm{L}$ Chlorine maximum residual disinfectant level

Table 7. Nitrate-nitrogen (Source: Author's research data, 2016).

\begin{tabular}{cccccc}
\hline $\begin{array}{c}\text { Sample } \\
\text { Brands }\end{array}$ & $\begin{array}{c}\text { Final reading Initial reading } \\
(\mathrm{mL})\end{array}$ & $\begin{array}{c}\text { Volume }(\mathrm{mL}) \text { used for } \\
\text { blank sample }(\mathrm{B})\end{array}$ & $\begin{array}{c}\text { Volume }(\mathrm{ml}) \text { used } \\
\mathrm{H}_{2} \mathrm{SO}_{4}(\mathrm{~A})\end{array}$ & $\begin{array}{c}\text { Nitrate } \\
(\mathrm{mg} / \mathrm{L})\end{array}$ \\
\hline TEX & 1.9 & 0.0 & 0.1 & 1.9 & 20.16 \\
Blue Diamond & 2.6 & 1.9 & 0.1 & 0.7 & 6.72 \\
JAH & 3.6 & 2.6 & 0.1 & 1.0 & 10.08 \\
JAGISA & 4.4 & 3.6 & 0.1 & 0.8 & 7.84 \\
KUMA & 5.1 & 4.4 & 0.1 & 0.7 & 6.72 \\
\hline
\end{tabular}

(WHO GUIDELINE, $1984 \leq 10)$ [12]. (USEPA MCL 10/1996 = 10) [13].

Table 8. Residual chlorine (Source: Author's research data, 2016).

\begin{tabular}{cccccc}
\hline Sample brands & $\begin{array}{c}\text { Final reading Initial reading } \\
(\mathrm{mL})\end{array}$ & $\begin{array}{c}\text { Volume } \\
(\mathrm{mL})\end{array}$ & $\begin{array}{c}\mathrm{g} / \mathrm{L} \text { of residual }(\mathrm{b}) \\
\text { chlorine }(\mathrm{X})\end{array}$ & $\begin{array}{c}\mathrm{mg} / \mathrm{L} \text { of residual } \\
\text { chlorine }\end{array}$ \\
\hline KUMA & 0.1 & 0.0 & 0.1 & 0.0013 & 1.3 \\
JAH & 0.2 & 0.1 & 0.1 & 0.0013 & 1.3 \\
TEX & 0.3 & 0.2 & 0.1 & 0.0013 & 1.3 \\
JAGISA & 0.4 & 0.3 & 0.1 & 0.0013 & 1.3 \\
Blue Diamond & 0.5 & 0.4 & 0.1 & 0.0013 & 1.3 \\
\hline
\end{tabular}

(USEPA MCL 10/1996 = $4 \mathrm{mg} / \mathrm{L}$ ) [13]. 
goal (MRDLG) are eye/nose irritation; stomach discomfort, etc.

Chlorine in one of a number of forms added to water to destroy or deactivate disease-causing microorganisms and is the mostly widely used disinfectant in the United States. Elevated chlorine levels can cause great aesthetic problems (strong taste and odor) and if organic matter is present it can result in the creation of trihalomethanes, which are potentially carcinogenic with target organs including the liver and kidney [17].

\subsubsection{Alkalinity}

Following the procedure to test for alkalinity (Table 9), the colour change that was required to prove the presence of carbonate which is pink after $1-2$ drops of phenolphthalein was not shown by any of the water samples. This was done thrice for more confirmation. This shows that all the sachet waters are free from carbonate alkalinity.

Alkalinity and total hardness are usually nearly equal in concentration when both are reported in $\mathrm{mg} / \mathrm{L} \mathrm{CaCO}_{3}$ (calcium carbonate), because they come from the same minerals. If alkalinity is much higher than total hardness in an unsoften sample, consider testing for sodium [17].

The lower the alkalinity, the more likely water is to be corrosive. Looking at the $\mathrm{pH}$ reading for all the water samples, it proves that none of the sachet waters fall in the alkaline range. Alkalinity, $\mathrm{pH}$, corrosivity and hardness are all related.

\subsection{Bacteriological Analyses}

\subsubsection{Total Coliforms}

Two of the sachet waters JAH and KUMA proved to be free from total Coliforms bacteria. This means that no bacteria can be found in them (Table 10).

But TEX, Blue diamond, and JAGISA contains total Coliforms above the maximum contaminant level goal (MCLG) set by the USEPA which is 0 and even more than the Colony Forming Units (CFU)/100 ml set by WHO, with JAGISA having the highest above the standard set by the WHO.

These organisms are prolific in the soil. Their presence does not necessarily imply contamination from wastewater nor the presence of other sanitation based health risks. The presence of total Coliforms by itself does not imply an imminent health risk but does indicate the need for an analysis of all water system

Table 9. Alkalinity (Source: Author's research data, 2016).

\begin{tabular}{cc}
\hline Sample & Alkalinity $\mathrm{mg} \mathrm{CaCO}_{3} / \mathrm{L}$ \\
\hline KUMA & 0.0 \\
JAH & 0.0 \\
TEX & 0.0 \\
JAGISA & 0.0 \\
Blue Diamond & 0.0 \\
\hline
\end{tabular}

(WHO GUIDELINE, $1984=500 \mathrm{mg} / \mathrm{L})$ [12]. 
Table 10. Total coliforms (Source: Author's research data, 2016).

\begin{tabular}{ccc}
\hline Sample & Total Coliforms count & Total Coliforms growth (CFU/100 ml) \\
\hline Blank sample & Nil & Nil \\
JAH & Nil & Nil \\
KUMA & Nil & Nil \\
TEX & 3 & 30 \\
Blue Diamond & 2 & 20 \\
JAGISA & 13 & 130 \\
\hline
\end{tabular}

(WHO GUIDELINE, $1984 \leq 10$ ) [12]. [USEPA Maximum Contaminant Level Goal (MCLG), 10/1996 = 0 . $\mathrm{MCL}=5 \%$ (not more than 5\%)] [13].

facilities and their operations to determine how these organisms entered the water system. Public notice to water system users is required since a properly constructed and maintained water system should not have total Coliforms present. When only total Coliforms are present, the water system is allowed 30 days to give public notice to customers that the water has violated a drinking water standard. This lengthy period indicates regulatory agencies' perception of a low degree of immediacy to the risk

(http://des.nh.gov/organization/divisions/water/dwgb/index.htm).

Important exceptions to this generalization include protozoa such as Giardia and Cryptosporidium, which can be present in water even when the total coliforms test shows an absence of organisms. Under such circumstances illness could occur. Nevertheless, the total coliforms test remains the most commonly used standard for determining the bacterial quality of drinking water in the US and the world.

\subsubsection{Faecal Coliforms}

The five brands of sachet waters proved to be free from faecal coliforms after the membrane filter technique used for the determination of faecal coliforms bacteria. This proves that their chlorination method, ozonation or ultraviolet radiation if available is able to treat the water very well to free it from faecal coliforms. Diseases that are likely to be caused by faecal coliforms bacteria such as $E$. coli in drinking water will not infect or affect anyone drinking these sachet waters (Table 11).

\subsubsection{Non-Faecal Coliforms}

From the analysis, two of the samples which are JAH and KUMA showed negative for non-faecal coliforms bacteria. This might be because of their system maintenance were in the very source from which they extract the water for purification is well taken care of, their filtration process is very adequate, and also their disinfection method of chlorination is well appropriate to destroy the microbes (Table 12).

The analysis proved TEX, Blue diamond, and JAGISA to be positive of nonfaecal coliforms, in which JAGISA proved to be the highest of $100 \mathrm{CFU} / 100 \mathrm{ml}$ 
Table 11. Faecal coliforms (Source: Author's research data, 2016).

\begin{tabular}{ccc}
\hline Sample & Faecal Coliforms count & Faecal Coliforms growth $(\mathrm{CFU} / 100 \mathrm{ml})$ \\
\hline Blank sample & Nil & Nil \\
JAH & Nil & Nil \\
KUMA & Nil & Nil \\
TEX & Nil & Nil \\
Blue Diamond & Nil & Nil \\
JAGISA & Nil & Nil \\
\hline
\end{tabular}

CFU $=$ Coliform Forming Units. (WHO GUIDELINE, $1984=0.0)$ [12]. (USEPA MCL, 10/1996 $\leq 1 / 100)$ [13].

Table 12. Non-faecal coliforms (Source: Author's research data, 2016).

\begin{tabular}{cc}
\hline Sample & Faecal Coliforms $(\mathrm{CFU} / 100 \mathrm{ml})$ \\
\hline Blank sample & Nil \\
JAH & Nil \\
KUMA & Nil \\
TEX & 30 \\
Blue Diamond & 20 \\
JAGISA & 130 \\
\hline
\end{tabular}

(WHO GUIDELINE, $1984 \leq 10)$ [12].

non-faecal coliforms. This showed that they contain other microbes apart from faecal coliforms such as E. coli. This might be because of the lack of system maintenance, inadequate filtration, or not very good disinfection with chlorine.

These bacteria occur naturally in the intestinal tracts of humans and animals and in the soil. Although coliforms bacteria normally do not cause illnesses, they should not be present in drinking water. The presence of these bacteria in the drinking water indicates that the water may be contaminated with other organisms that can cause diseases. Diseases symptoms may typically include diarrhea, cramps, nausea, and any associated headaches and fatigue.

Bacteria in the digestive tract can cause methaemoglobinaemia when they convert nitrate to nitrite. Nitrite reacts with hemoglobin in the blood, producing methemoglobin which cannot carry oxygen. The resulting oxygen starvation causes a bluish discoloration of the body. The condition is largely confined to infants less than 9 months old.

\section{Conclusions}

The physical parameters which are temperature, electrical conductivity, turbidity, and total dissolved solids tested for in the water samples proved to be alright for drinking purposes because they are below the WHO standards and USEPA maximum contaminant level (MCL) with the exception of temperature which falls above the WHO standard of $25^{\circ} \mathrm{C}$ for all the samples. From the results, it 
can be seen that the temperature values are not consistent which might be because of the environmental condition in which the samples were stored.

For the chemical parameters such as the $\mathrm{pH}$, all the samples fell outside (Below the range) set by the WHO and USEPA. This affected the alkalinity of the samples to be zero for all the samples which proved the acidity and corrosivity of the sachet waters. The lower the alkalinity, the more likely water is to be corrosive. Looking at the $\mathrm{pH}$ reading from the results for all the water samples, it proves that none of the sachet waters fall in the alkaline range.

The chemical oxygen demand (COD) tested for, proved TEX, JAH and JAGISA, to fall below the WHO standard, and KUMA and Blue Diamond to be above standard. This shows that the dissolved oxygen content in KUMA and Blue Diamond is small with Blue Diamond having the smallest. This can have a negative effect on the odour of the sachet water when stored for a long time, and will make the water unsuitable for drinking. A reduction in DO can lead to anaerobic conditions, which is deleterious for drinking and even for aquatic life.

Blue Diamond, JAGISA, and KUMA fell below the maximum contaminant level (MCL) for Nitrate-nitrogen set by the WHO and USEPA. But TEX and JAH fell above the standard, which proved them to be bad for infants below six months and pregnant women's consumption. This is because it has been proved that nitrate-nitrogen above $10 \mathrm{mg} / \mathrm{L}$ in drinking water sample can cause methemoglobinemia, birth defects, and miscarriages. It also suggests that other contaminant may be present [16].

The residual chlorine level for all the sachet waters are below the maximum contaminant level (MCL) set by the USEPA. This proves the carefulness of the companies when adding chlorine for disinfection purposes.

For the bacteriological analysis, all the water samples were assessed to be free from faecal Coliforms. But in the case the total Coliforms, only JAH and KUMA were free from total Coliforms. TEX, Blue Diamond, and JAGISA proved to contain total Coliforms above the WHO and USEPA standard. This shows that even though they contain no faecal Coliforms, they contain non-faecal coliforms bacteria, which makes them very liable of containing other microorganisms that can cause diseases with symptoms such as diarrhoea, cramps, nausea, and any other associated headache and fatigue [17].

In conclusion, none of the sachets water completely met the WHO and USEPA standards set for drinking water quality. Therefore, they are not completely fit for drinking purposes.

\section{Recommendations}

The following were the recommendations from the research:

1) All the sachets should have batch numbers for easier identification.

2) The vicinity where the sachet waters are produced must be under investigation by the ministry of water resources to see if they are up to standard for drinking water production. A hygienic area is the most recommendable area for 
drinking water production.

3) The source of the sachet water which might be a stream or river etc. must be well maintained to prevent run-off from entering the water system. This is because I found the total Coliforms, nitrate and chemical oxygen demand level in some of the water samples to be high.

4) The companies that produced these sachet waters must be thoroughly investigated concerning the processes they are using to produce the sachet water. The ministry should do this unannounced in order to see the reality of their production.

5) Well trained personnel in terms of water quality should be employed in each company for a hygienic production of sachet water.

\section{References}

[1] (2010) Africa's Water Quality. A Report by the Pan Africa Chemistry Network, March 2010.

[2] (2014) African Health Observatory. Analytical Summary-Physical Environmental.

[3] World Health Organization (2012) Cholera in Sierra Leone: The Case Study of an Outbreak. September 2012.

[4] (2015) Sierra Leone Population and Housing Census. Statistics Sierra Leone.

[5] Washington State Department of Health (2016) Coliforms Bacteria in Drinking Water.

[6] World Health Organization (1996) Guidelines for Drinking-Water Quality. Microbiological Methods, 2nd Edition, Vol. 1, Geneva.

[7] Prescott, L.M., Harley, J.P. and Klein, D.A. (1999) The Influence of Environmental Factors on Growth. Microbiology, 4th Edition, McGraw-Hill, USA.

[8] World Health Organization (2010) Guidelines for Drinking-Water Quality. The Guidelines Text Is Kept Updated through the Rolling Revision Process. http://www.who.int/water_sanitation_health/dwq/gdwq3rev

[9] Pangborn, R.M. and Bertolero, L.I. (1972) Influence of Temperature on Taste Intensity and Degree of Liking of Drinking Water. Journal of the American Water Works Association, 64, 511-515. https://doi.org/10.1002/j.1551-8833.1972.tb02739.x

[10] McKee, J.E. and Wolf, H.W. (1963) Water Quality Criteria. 2nd Edition, State Water Quality Control Board, Sacramento, CA.

[11] WHO (1998) Guidelines for Drinking-Water Quality. 3rd Edition, Vol. 1, World Health Organization, Geneva, Switzerland.

[12] World Health Organization (1984) Drinking Water. http://www.USEPA.gov/safewater/standard/setting.html

[13] Frequently Asked Questions (FAQs). Turbidity Education and Notification Campaign.

[14] U.S. Environmental Protection Agency (1996) Drinking Water and Health: What You Need to Know. http://www.USEPA.gov/safewater/dwh/dw-health.pdf

[15] Bhawalker, U.S. (2008) Guidelines on COD and BOD Limits in Drinking Water. 19 May 2008.

[16] Mechenich, C. and Andrews, E. (2004) Home Water Safety.

[17] Oram, P.B. (2014) Alkalinity and Stream Water Quality. http://www.water-research.net/index.php/the-role-of-alkalinity-citizen-monitoring 